\title{
TANULMÁNYOK
}

HoRVÁth ZsuzsanNa

\section{Mozgás és testtudat - egy módszer tükrében}

\begin{abstract}
„Könnyen lehet, hogy a tánc mindenekelött a kitérök nélküli, közvetlen kommunikációt kísérli meg. Hiszen hordozója és közvetítö közege maga az ember, kifejezésének eszköze pedig az emberi test, melynek természetes mozdulatai szolgálnak a tánc anyagául, ami az egyedüli anyag, mely az ember sajátja és sajátjaként is használhatja."
\end{abstract}

(Mary Wigman)

A jelen tanulmány egy hazai mozgás- és táncterápiás módszer, a pszichodinamikus mozgás- és táncterápia bemutatását túzi ki célul, annak munkamódjain és fontosabb kapcsolódó fogalmain (test, mozgás, interszubjektivitás) keresztül. Ezt a testélményalapú, nonverbális módszert elsősorban csoportterápiára használják. Egyszerre vannak jelen benne az egyén és a csoport dinamikai jellemzői és összefüggései.

\section{BEVEzetÉs}

A jelen írásban univerzális fogalomhasználatra törekszem, középpontjában az emberi tapasztalatszerzés áll; mindazonáltal kitérek a mozgás- és táncterápiás folyamatok különböző csoportokban történő megvalósulási sajátosságaira is. Jóllehet a Fogyatékosság és társadalom c. folyóirat hasábjaira írom soraimat, mégis azt gondolom, hogy a testről és a testi tapasztalatokról, a mozgásról, a térröl vagy az interszubjektivitásról írni tágabb perspektívából érdemes. Nem fogyatékosságspecifikus fogalmak ezek, sokkal inkább emberi minőségünk dimenzióinak és tapasztalatainak tükrében járhatóak körbe. 
Tanulmányomban elsősorban egy hazai mozgás- és táncterápiás módszer munkamódjain keresztül mutatom be a fenti fogalmakat. Terápiás munkám során akár fogyatékossággal élő személyekkel dolgozom, akár nem, a térnek, az interszubjektív élményeknek, a (testi) reflektivitásnak minden esetben kiemelt jelentősége van. A mozgásterápia során leginkább használt eszközünk a saját testünk és hangunk, vagyis térérzékelésünk állandó kiindulási pontjai, melyeknek különböző minőségei minden terápiás folyamatban jelen vannak. Azokban a terápiás módszerekben, ahol a test központi szerepet játszik, a testi tapasztalatok különféle minőségeinek átélése döntően befolyásolja az élmények szerveződését. A testtel dolgozó terápiák során tehát a tér, a mozgás, a test különböző szintű tapasztalása történik, ami aktivizálja a megfelelő élményrétegeket és az azokhoz kapcsolódó érzelmi-indulati állapotokat.

A testtel kapcsolatban különböző tudományterületek, különböző szakmák másmás elemeket helyeznek előtérbe: az orvoslás a szervezet müködőképességét, a testen belül és kívül lévő problémák gyógyítását; a sport a test mozgáskészségének és teherbírásának növelését; a média a legtöbb esetben a test kirakatba helyezését. A test fogalma, a test maga több diszciplína felöl is megközelíthetö. Értelmezhetjük elsődlegesen biológiai szempontból, mint szervezet, amely ily módon létezésünk feltétele és eszköze (corpus, soma), definiálhatjuk azonban filozófiai és/vagy esztétikai perspektívák mentén (Shusterman, 2015) vagy az előadóművészetek kontextusában (Müller, 2009), de a társadalmi (hatalmi) diskurzus részeként (Hernádi, 2014) is. Testünk - akár mozgásban van, akár nem -, emberi és személyes identitásunk alapját képezi (Csabai, \& Erős, 2000), testképünk pedig magában foglalja perceptuális tapasztalatainkat és konceptuális tudásunkat a testünkröl, illetve érzelmi viszonyulásainkat a saját testünkhöz (Ábrahám, Jambrik, John, Németh, Franczia, \& Csenki, 2017). E tudásunkat és magát a testet is körbeveszi a mindenkori, körülöttünk lévő kulturális-társadalmi kontextus. A testkép - „az én hordozója” -, elválaszthatatlan az egyén szubjektív testtapasztalásától, annak személyes megélésétől, amely fizikai és mentális szinteken is megjelenik. Husserl, a fenomenológiai irányzat atyja, megmutatta, hogy az egyén testélménye eleve kettős természetű, vagyis alanyi és tárgyi is egyben, hiszen a testet belülröl is állandóan tapasztaljuk, ugyanakkor külső tárgyként is érzékeljük (Vermes, 2008). A térérzékelésünk középpontja is az egyén maga, mivel a test adja az orientáció centrumát, az képezi az „itt és most”-ot, amelyhez képest minden más „ott” van. A test nem csupán viszonyítási alap, hanem az átélt élmények hordozója is: ha az ember megtapint valamit, a taktilis minőségeket is saját testében fedezi fel (Behnke, 1997). A mozgás- és táncterápiás folyamatoknak is egyik lényegi vonása a testi észlelések, érzetek és a tudatosság összekapcsolása (Vermes, 2008).

A pszichodinamikus mozgás- és táncterápia (PMT) egy nonverbális, elsősorban csoportterápiás módszer, amelyet önismereti, pszichoterápiás, szocioterápiás és múvészetterápiás szinteken és színtereken alkalmaznak. Mind a mozgás- és táncterápia pszichodinamikus formája, mind annak adaptált változata alapelemeiben kapcsolódik a mozgásalapú, fejlesztési fókuszú, gyógypedagógiai eljárásokhoz. Ezek az illeszkedési pontok megjelennek a mozgás mint a tapasztalatszerzés elsődleges formájának koncepciójában, a verbális és non-verbális kommunikáció jelentőségében vagy a szociális készségek/képességek fontosságában.

Az egyes országokban eltérőek a mozgás- és táncterápiás képzések. Van, ahol egyetemi mesterképzés (Egyesült Királyság, Egyesült Államok) keretein belül lehet táncterapeuta végzettséget szerezni, míg Magyarországon a pszichodinamikus 
mozgás- és táncterápiás csoportvezetői képzés a Magyar Mozgás- és Táncterápiás Egyesület keretei között zajlik. A különböző mozgás- és táncterápiás módszerek között is vannak különbségek, de az alapjuk - a testtudati munka - közös.

A mozgás- és táncterápiás eljárásokat kísérő kutatások elsősorban kvalitatív kutatásmódszertani paradigmából közelítenek (Koch, Kunz, Lykou, \& Cruz, 2014), ennek oka a múvészetalapú terápiás eljárások természete, amely a tudás megszerzésének szubjektív útjára helyezi a hangsúlyt. A vizsgált jelenség holisztikus szemlélete mentén az objektív és szubjektív komponensek nehezen elkülöníthetőek (Illyés, 2012). A szakirodalomban találkozhatunk azonban kvantitatív megközelítésű kutatásokkal (Brauninger 2014), illetve kevert módszertanú és múvészet alapú kutatásokkal is. Ez utóbbinál a különböző művészeti modalitások révén a résztvevői nézőpontok a maguk képlékenységében válnak rekonstruálhatóvá (Leavy, 2015).

A nemzetközi és hazai területeken fellelhető korábbi kutatások és szakirodalom alapján a mozgás- és táncterápiás módszereket sikeresen alkalmazzák pszichoszomatikus és evészavaros felnőtteknél és gyerekeknél (Kleinmann-Hall, 2005; Ressler-Kleinmann, 2006), gyermekkori vagy felnőttkori szexuális abúzust, háborús traumát átélt egyéneknél (Kornblum-Halsten, 2006; Harris, 2007), depresszióval diagnosztizált betegeknél (Koch, Morlinghaus, Fuchs, 2007), illetve kapcsolati elakadással küzdőknél - legyenek azok párok vagy családok (Payne, 2004).

További kutatásokból és tanulmányokból az is kiderül, hogy a mozgás és a tánc milyen fejlesztési lehetőségeket rejt magában a fogyatékossággal élő gyermekeket tekintve (Matzner, 2015; Gonzalez, 2015; Albin, 2016; Barthel, Fodorné, Rácz, \& Bognár, 2009). A témához kapcsolódóan találunk még nem fogyatékosságspecifikus szakirodalmat is, különös tekintettel a kognitív területek fejlödésére (Barhorst, 2013; Balgaonkar, 2010) vagy az érzelmi/mentális jóllétre (Hervey, \& Kornblum, 2006; Somerstein, 2010).

A pszichodinamikus mozgás- és táncterápia a testtudati gyakorlatokat, a mozgásos improvizációban rejlő alkotó és gyógyító lehetőségeket összekapcsolja a csoportterápia eszközeivel (Merényi, 2015). Egyszerre figyel az egyén testi-lelki érzéseinek dinamikájára (változásaira, feszültségeire) és a csoportdinamikára, a csoportban megszülető testi-lelki érzések változásaira, összefüggéseire. A dinamika fogalmának jelentősége nem csupán a terápiás színtereken jelenik meg, hanem mindennapi életünk részét is képez(het)i. Mindenkinek van saját belső dinamikája, saját története, múltja, jelene és jövője, vannak kapcsolatai a praktikus világban, dolgozik, más emberekkel van körülvéve. Emellett saját problémái, feszültségforrásai befolyásolják viselkedését, érzelmeit és hatással vannak a tetteire. De nem különíthető el a saját lelki dinamikai történés a más emberekkel történő interakcióinktól. Hiszen elsődlegesen viszonyrendszerekben élünk és gondolkozunk; az segít keretbe helyezni és biztonságban tartani az ént, ahogyan érzékeljük magunkat a másik tekintetének tükrében. Az interszubjektivitásnak is egyik központi eleme a másik intencióinak olvasása, ami lehetővé teszi, hogy a két fél (szubjektum) részt vegyen egymás tapasztalásában. Ebben a folyamatban egyszerre van jelen annak a tudása, hogy a másik mit tapasztal és az is, hogy a másik hogyan tapasztalja meg őt magát (Stern, 2002; Ajkay, 2008).

Terápián kívüli kapcsolatainknak - legyen az barátság, párkapcsolat, csoportlét - is meghatározó dinamikája van. Csak éppen a mindennapokban történő dinamikai változásokra kevesebb reflexióval reagálunk, mint egy olyan terápiás helyzetben, ahol fókuszba kerül a dinamikai aspektus, a tag(ok) szempontjából a szabad 
megélés, a vezető(k) részéről pedig a strukturálás tekintetében. Az egyéni dinamikák feltérképezése azonban megtörténhet négyszemközti, egyéni terápiában is, a viszonyok mélyebb megismeréséhez lehet inkább szükség zárt csoportra (Horváth, 2015). Minden csoport rendelkezik univerzális és sajátos jellemzőkkel is, olyan dinamikával, amelyet a benne lévő tagok határoznak meg (Yalom, 2001; Rudas, 2016; Horváth, 2015). A csoport kialakulásának Tuckman (1965) óta négy általánosan elfogadott szakasza van: az alakulás, a viharzás, a normakészítés és a müködés. Ezek a szakaszok - kiegészülve a csoport lezárásával - a PMT metodikájának is részét képezik.

A PMT folyamata négy, egymással szervesen összefüggő munkamódból áll. Ezek a munkamódok - lehetőség szerint - fogyatékossággal élő tagokból álló csoportokban is illeszthetőek a folyamathoz. Az alkalmak verbális körrel (verbális munka) kezdődnek és zárulnak. Ennek segítségével az emocionális és a kognitív szintek is elérhetőek. A nyitó verbális munka egyfajta bejelentkezés a két alkalom között történt élményekröl, eseményekről és az általuk kiváltott érzelmekről.

A mozgásos részt követő záró verbális visszajelzés elsősorban a mozgásban megélt élmények szóbeli visszafordítását, az emlékezést és az áttételi történések kellő időben való feltárását, átdolgozását tartalmazza, reflektálva a csoporttagokra és a vezetőkre is. Ekkor van lehetőség az alkalom elejéhez képest történt változások megfigyelésére is.

A nyitókört követően az alkalom mozgásos része következik, amelynek bevezető szakasza a bemelegítés. Ez szinte mindig a tér bejárásával kezdődik. A test a tér részévé válik, a beszéd, a hangok szerepét átveszi a saját test érzékelése, így a térnek is új minőséget ad a test elmozdulásának megtapasztalása. A figyelem változó fókuszaival egyszerre érzékeljük saját testi jelenlétünket, társainkat és a mozgás közben új arcát mutató, „kinyíló” tárgyi teret.

Sétáljunk a térben. Ismerd meg ezt a régi-új teret. Ebben a formában régen találkoztunk a térrel. Megkeresheted a kedvenc helyeidet, ha vannak, de odamehetsz olyan helyekre is, ahol nem szoktál dolgozni. Közben melegitsük be a testünket, érezd, hogy mire van szükséged. Nyújtózásra, hajlásra, ugrásra vagy állásra.

A bemelegítés általában rövidebb, dinamikusabb gyakorlatokból áll, amelyek a térmunkán túl a csoport és az egyén hangolódását is segítik. Ez vetíti előre az úgynevezett testtudati fókuszt, a testtudati munkát és a további mozgásokat egyaránt. A testtudati fókuszt a csoportvezetők általában elöre meghatározzák. Ez az aktuális testtudati munka központja, majd a testtudati munka elemeinek folyamatos egymásra épülése és megtapasztalása teszi teljessé a testről alkotott képet (Horváth, 2015).

\section{TESTTUDATI MUNKA}

A legtöbb hétköznapi tapasztalás testi szinteken nem tudatos és nem figyelemmel kísért állapot, holott tapasztalataink nagy részét - csecsemőkortól kezdődően - testi érzetekkel szerezzük meg (Horváth, \& Novák, 2014). Testtudatnak a saját test fizikai minőségeinek részletes tudatosítási folyamatát nevezzük, amely egyrészt magába építi, másrészt azonban túl is mutat a testséma, testkép fogalmakon, mivel a moz- 
gás, a figyelem és a ,jelenlét” segítségével egyfajta folyamatos testi reflektivitáshoz vezet (Merényi, 2004). A testtudati munka célja épp ezért az, hogy a megszokott, hétköznapi jelenléttől egy merőben más tapasztaláshoz lehessen jutni. Alapja a konkrét mozgásra és testre irányuló figyelem, a test aktív érzékelése és állapotváltozásainak lekövetése (Incze, 2008). A testtudati munka a test valóságára, az érzékelés lehetőségeire épít, így teremtve meg azt az állapotot, amelyben átélhető a hatóerő (önmagunk) élménye és megvalósulhat a testi szintek reflektivitása. Ez a sajátos figyelmi állapot szinte teljesen betölti a tudatot, elősegítve a folyamatos önészlelés és önfelfedezés élményét és a testünkkel, önmagunkkal való kísérletezés lehetőségeit. Testtudati fókuszt jelenthet a súly-egyensúly érzékelése, az irányok, a testrészek részvétele, a szimmetriaviszonyok, a térhez való viszony, az erő, a ritmus és a sebesség, a forma vagy a test külső és belső tere (Horváth, 2015).

A lélektani munkát is a testtudati munka alapozza meg, amikor is a konkrét (valós) testi tapasztalás talaján bontakoznak ki a mozgás szimbolikus minőségei és a lélektani tartalmak összefüggései. A testtudati munka lehetőséget ad a belső testkép differenciálódására, a mozgásrepertoár bővülésére és az improvizációs készség fejlödésére is (Merényi, 2004).

\begin{tabular}{lll}
\hline $\begin{array}{l}\text { Testtudati } \\
\text { fókusz }\end{array}$ & $\begin{array}{l}\text { Testtudati fókuszhoz köthető kérdések } \\
\text { bemelegítéshez }\end{array}$ & $\begin{array}{l}\text { Kapcsolódó testtudati } \\
\text { fókuszok }\end{array}$ \\
\hline & $\begin{array}{l}\text { Milyen irányban esik jól haladni, mozogni? } \\
\text { Van-e olyan helyzet, amikor a törzsünk és } \\
\text { a végtagjaink más irányokba indulnak? }\end{array}$ & \\
& Mi indítja el a különböző irányokba történő & végtagok \\
mozgásokat? & gerinc, központ \\
Irányok & $\begin{array}{l}\text { Hogyan tudunk elöre-hátra-jobbra-balra } \\
\text { haladni? }\end{array}$ & járás, haladás \\
& Hogyan esnek ezek az irányok? & szintek \\
& $\begin{array}{l}\text { A hirtelen irányváltások vagy az áramlásos } \\
\text { irányváltások esnek jobban? }\end{array}$ & \\
\hline
\end{tabular}

(A táblázatot a szerző állította össze.)

Sétáljunk a térben, majd séta közben váltsunk hirtelen irányt, magunkat is meglepve ezekkel a váltásokkal, majd ezeket a hirtelen irányváltásokat változtassuk meg és az irányváltásoknak legyen egymásba való átmenete, áramlása.

Ezt engedjük el és alkossunk párokat. A páros egyik tagja megfogja a másik homlokát vagy fejtetőjét, és ezzel az érintéssel kísérjük a társunk mozgását. A mozgást az vezeti, aki kapja az érintést, kipróbálhat irányokat, szinteket, sebességet.

\section{KAPCSOLATI MUNKA}

A kapcsolati munka során egyszerre figyelünk a saját mozgásunkra, szándékainkra és a másikéra, miközben folyamatos finomhangolódás történik. A társakkal való 
mozgásos kapcsolatban átélhető a „szelfszabályozó másikkal” való kölcsönösség és elismertség élménye (Merényi, 2004). Kapcsolati vagyis páros, hármas, kiscsoportos vagy csoportos munkánál is az egyéni vagy több személyre építő testtudati tapasztalat a kiindulási pont. A közös mozgást az egymásra hangolódás, a kölcsönös munka és figyelem határozza meg. Ekkor már a szubjektív szelférzet is bekapcsolódik, a megosztott szándék vagy megosztott affektivitás mentén.

Az összehangolt együttmozgásokban átélhető a másikkal közös figyelmi fókusz, hiszen együttmozgáskor nemcsak a saját mozgásunkra, hanem a másikéra is figyelünk. A közös mozgás során az egyén érzékeli a saját szándékait és mozgását, miközben folyamatosan érzékeli a másikat is, vagyis testen és mozgáson alapuló élménymegosztás történik (Merényi, 2004). Interszubjektív találkozások ezek, érzelmileg telített, jelentőségteljes, meghatározó tapasztalatok egy csoportfolyamat során. A másik személlyel való kölcsönös munka, az egymásra hangolódás pozitív vagy az elhangolódás negatív élményei meghatározzák a közös mozgást, később pedig, az alkalom végén a verbális átdolgozás szintjeit is áthatják.

Fontosak a sajátos csoportdinamikai történések is, a csoport együttes müködése és ereje. A kapcsolati munka után sok esetben lehetőséget kapnak a csoporttagok egyedüli munkára, hogy a kapcsolatban megtapasztalt mozgásos és térbeli élmények beépíthetővé, továbbfejleszthetővé válhassanak az egyén saját történetébe, ami segíti az egyéni dinamika feszültségeinek oldódását.

Az imént szerzett érzetekkel sétáljunk egy keveset a térben és alkossunk hármasokat egy hosszabb munkára. A gyakorlat során a középen álló mozgását kísérik társai. A középen álló két tenyerével a társai tenyerei kapcsolódnak, így válnak a mozgó kísérőivé. A mozgónak lehetősége van kipróbálni irányokat, megállást és elindulást, sebességet, szinteket - a társai mindebben segítik őt. A mozgó vezeti, irányítja a folyamatot, a középső egy idő után egyedül is fog mozogni, a társai figyelik öt. A hármas minden tagja lesz középen. A szerepcseréket követöen megszünnek a szerepek. Együttmozgás következik, amikor már nincs kimondott irányitó, vezető. Egy kis idő elteltével a hármasok szétválnak és mindenki egyedül mozog tovább.

\section{Alkotás}

A testtudati és kapcsolati munka során a test integrált egészként való érzékelése történik. Ez által nő az egyén improvizációs készsége és a kezdeti mozgásanyagok egyre árnyaltabban, differenciáltabban formálódnak meg. Az önfelfedezés összefonódik az önalkotás élményével. Megjelenik a kiemelt térben történő improvizáció, ami azt jelenti, hogy a csoporttagok egyedül, párban, hárman vagy négyen, a többiek, azaz a „nézők” figyelmével kísérve dolgoznak a terápiás térben (Merényi, 2015). Minden mozdulat magában hordozza az összes előző hasonló mozdulatot, a terápiás térben átélt élményeket, illetve a csoportban jelen lévő aktuális érzelmi tartalmakat, dinamikákat. A kiemelt tér egyik formája az „út”, amelynek maga a fizikai tér ad keretet, instrukciótól függően hosszában, széltében vagy saroktól sarokig. Továbbá az út fogalmából is fakadóan van iránya, illetve eleje, közepe és vége, ezáltal története és ideje, ami időben is strukturálja a mozgást. 
Egy klasszikus értelemben vett - hosszú, 250-300 órás, önismereti célú, ép, felnőtt személyekböl álló - mozgás- és táncterápiás csoportfolyamatban a munkamódok arányosan, a csoport dinamikájának megfelelően jelennek meg az általában 5 órát felölelő alkalmakon. A verbális bejelentkezést a bemelegítés követi, amely elöre vetíti a testtudati fókuszt és a testtudati munkát. Ezután a kapcsolati munka következik, végül - a csoport aktuális állapotához és dinamikájához illesztetten - az alkotás munkamódjával zárul az alkalom mozgásos része. A záró verbális visszajelzésekre ezt követően kerül sor. A munkamódok alkalom és folyamat szerinti megoszlása természetesen változó lehet - résztvevők, korosztály, célok, időbeli és térbeli keretek függvényében.

A mozgás- és táncterápiás folyamat elméleti és szemléleti alapjai minden csoportban azonosak, de a megvalósításuk különböző lehet. Más kereteket szükséges biztosítani egy kamasz- vagy gyerektagokból álló csoportnak, mint egy felnőtt résztvevőkből álló csoportnak. Lényeges szempont az is, hogy a vezetők a mindenkori résztvevőkhöz illesztik a terápiás folyamat céljait és lehetőségeit. A verbális kifejezés nehezítettsége esetén - ami esetünkben összefüggést mutathat a fogyatékos személyekből álló csoportokkal -, a verbális munkamódot is mozdulat(ok) váltják ki. A mozgás- és táncterápiás folyamat fókuszába így nem a beszéd segítségével elérhető kognitív szintre emelés kerül, hanem a mozdulat szabadságának hatóereje és a csoport mint szociális mikrokozmosz.

A folyamat koncepciójának és céljainak áthangolása felvet bizonyos módszertani kérdéseket a klasszikus metodológia kiterjesztésének, a PMT adaptációs lehetőségeinek szempontjából. Ezek az említett verbalitás nehézségén túl olyan kérdéseket is érinthetnek, mint a csoport homogén vagy heterogén szempontú összeállítása vagy az intézményes keretek aspektusa. (Ezen kérdések megválaszolása jelen tanulmány kereteit meghaladja, fontos vizsgálódási terület azonban a PMT szakemberei számára.)

A PMT metodikájának általános jellemzője és fontos eleme továbbá a kettős vezetés. Így lehetőség van arra, hogy az egyik vezető testi jelenlétével, míg a másik kívülről, szóbeli instrukciókkal biztosítsa a csoport biztonságos kereteit. A testi jelenlét szorosan összefügg a testtudati munka által elérhető testi reflektivitás fogalmával, amely a mozgás közben átélhető interszubjektív élmények alapját is képezi. Az egymással kölcsönhatásban álló szubjektumok interakciói az egyén élettörténetébe ágyazódó tapasztalatok, az „énélmény” is interszubjektív közegben szerveződik (Stern, 2002; Halász, 2008). Egy mozgásos csoportfolyamat kapcsolódások és kapcsolatok révén ad lehetőséget az együttműködés és a nonverbális kommunikáció elemeinek megjelenésére és azok jelentéssel való megtöltésére. Ezek az ismétlődő interakciós láncok mentén még nem ismert tapasztalatokat tudnak nyújtani a résztvevők számára.

\section{Összegzés}

A mozgás során, a mozgás által érzékelhető testi és kapcsolati dimenziók létezésünk és mindennapi életünk egyik bázisát jelentik. $E$ tanulmány fókuszába is egy, többek között ezen a bázison nyugvó specifikus mozgás- és táncterápiás módszer bemutatásra került, amely szándékosan ritkán tér ki a fogyatékosság területére. A tanulmány 
témájában és fogalomhasználatában egyaránt univerzalitásra törekszik. Tudásunk saját magunkról, a másik emberről és a világról testi tapasztalataink révén valósul meg, és ebből az aspektusból vizsgálódva a test „milyensége” nem lényeges. Amenynyiben a kiindulási pontunk az ember, az emberi kapcsolódások és kapcsolatok, illetve esetünkben maga a módszer, akkor a figyelem és a terápiás folyamat fókusza nem a fogyatékosság vagy a sérülés, hanem az egész személy(iség).

\section{Felhasznált irodalom}

Ábrahám I., Jambrik M., John B., Németh A. R., Franczia N., \& Csenki L. (2017). A testképtől a testképzavarig. Orvosi Hetilap, 158(19), 723-730. https://doi.org/10.1556/650.2017.30752

Ajkay K. (2008). A korai szelf-fejlődés kapcsolati reprezentációinak hatása az áttételi-viszontáttételi történésekre. Pszichodráma, Különszám a mozgás- és táncterápiáról, 7-11.

Albin, C. (2016). the benefit of movement: Dance/movement: Therapy and down syndrome. Journal of Dance Education, 16(2), 58-61. https://doi.org/10.1080/15290824.2015.1061196

Balgaonkar, A. V. (2010). Effect of dance/motor therapy on the cognitive development of children. International Journal of Arts and Sciences, 3(11), 54-72.

Barhorst, E. (2013). The correlation of dance experience and spatial memory abilities. San Marcos, Texas: University Honors College at Texas State University. https://doi.org/10.1037/e633262013-467

Barthel B., Fodorné F. R., Rácz K., \& Bognár A. (2009). Alapozó terápia kontra értelmi akadályozottság? Gyógypedagógiai Szemle, 37(1), 26-32.

Brauninger, I. (2014). Specific dance movement therapy interventions: Which are successful? An intervention and correlation study. The Arts in Psychotherapy, 41(5), 445-457. https://doi.org/10.1016/j.aip.2014.08.002

Behnke, E. A. (1997). Body. In L. Embree (ed.), Encyclopedia of Phenomenology (pp. 67-71). Dordrecht: Kluwer Academic Publishers. https://doi.org/10.1007/978-94-017-5344-9_14

Csabai M., \& Erős M. (2000). Testhatárok és énhatárok: Az identitás változó keretei. Budapest: Jószöveg Mühely.

Gonzalez, S. (2015). A Movement And Music Program For Children With Autism. Dance Education in Practice, 1(1), 16-22. https://doi.org/10.1080/23734833.2015.990339

Halász A. (2008). Az élményszerveződés és interszubjektivitás. Pszichodráma Újság, Különszám a mozgás- és táncterápiáról, 34-39.

Harris, D. A. (2007). Dance/movement therapy approaches to fostering resilience and recovery among African adolescent torture survivors. Journal on Rehabilitation of Torture Victims and Prevention of Torture, 17(2), 134-155.

Hernádi I. (2014). Problémás testek. Nőiség, szexualitás és anyaság testi fogyatékossággal élő magyar nök önreprezentációiban. Doktori disszertáció. Pécs.

Hervey, L., \& Kornblum, R. (2006). An evaluation of Kornblum's body-based violence prevention curriculum for children. The Arts of Psychotherapy, 33, 113-129. https://doi.org/10.1016/j.aip.2005.08.001

Horváth Zs. (2015). A tér mint terápiás erő a mozgás- és táncterápiában. Konferencia-kötet. Térátlépések, Antropológiai Konferencia. Veszprém. 171-178.

Horváth Zs., \& Novák G. M. (2014). Az épség és alternatívái. Iskolakultúra, 24(7-8), 69-79.

Illyés S. (2012). Tudomány és gyakorlat a gyógypedagógiában In Gordosné Sz. A. (2012), Gyógyító pedagógia: Nevelés és terápia (pp. 55-70). Budapest: Medicina Kiadó.

Incze A. (2008). A testtudati munka mint a testi kreativitás mozgósítója. Pszichodráma Újság, Különszám a mozgás- és táncterápiáról. 40-47.

Kleinman, S., \& Hall, T. (2005). Dance movement therapy with women with eating disorders. In F. Levy (ed.), Dance/movement therapy: A healing art (pp. 221-227). Reston, V. A.: The American Alliance for Health, Physical Education, Recreation, and Dance.

Koch, S. C., Morlinghaus, K., \& Fuchs, T. (2007). The joy dance: Specific effects of a single dance intervention on psychiatric patients with depression. The Arts in Psychotherapy. 34(4), 340-349. https://doi.org/10.1016/j.aip.2007.07.001

Koch, S., Kunz, T., Lykou, S., \& Cruz, R. F. (2014). Effects of dance movement therapy and dance on health-related psychological outcomes: A meta-analysis. The Arts in Psychotherapy, 41(1), 46-64. https://doi.org/10.1016/j.aip.2013.10.004 
Kornblum, R., \& Halsten, R. L. (2006). In-school dance/movement therapy for traumatized children. In Brooks, S. (ed.), Creative Arts Therapies Manual (pp. 144-155). Springfield, IL: Charles C. Thomas Publisher.

Leavy, P. (2015). Method meets art - Arts-based research practice. Second Edition., New York, NY: The Guilford Press.

Leavy, P. (2017). Research design: Quantitative, qualitative, mixed methods, arts-based and community based participatory research approaches. New York: The Guilford Press.

Matzner, J. (2015). Sitting ballet: A pilot program designed to include children with physical disabilities in the private studio environment. Journal of Dance Education, 15(3), 116-121. https://doi.org/10.1080/15290824.2015.1055332

Merényi M. (2004). Mozgás- és táncterápia. Pszichoterápia, 13(1), 4-17.

Merényi M. (2015). Mozgás- és testélmény alapú pszichoterápiák, más nonverbális módszerek. In Szőnyi G. (szerk.) (2015), A pszichoterápia tankönyve (pp. 362-379). Budapest: Medicina Kiadó.

Müller P. (2009). Test és teatralitás. Balassi Kiadó, Budapest.

Payne, H. (ed.) (2004). Dance movement therapy: theory and practice. Hove - New York: Brunner-Routledge.

Ressler, A., \& Kleinman, S. (2006). Reframing body-image identity in the treatment of eating disorders. In Davis, W., \& Kleinman, S. (Eds.), Healing Through Relationship: Fostering Body-Mind Integration. The Renfrew Center Foundation Healing Through Relationship Series: Contributions to Eating Disorder Theory and Treatment. Volume 1. Philadelphia, PA: Renfrew Center Foundation.

Rudas J. (2016). Csoportdinamika. Budapest: Oriold és társai Kiadó.

Stern, D. N. (2002). A csecsemő személyközi világa a pszichoanalízis és a fejlődéslélektan tükrében. Fordította Balázs-Piri Tamás. Budapest, Animula.

Shusterman, R. (2015). A gondolkodó test. Fordította Antoni Rita, Bodóné Hofecker Zsuzsanna, Csuka Botond, Konkoly Ágnes, Krémer Sándor, Pavlovski Róbert. Szeged: JatePress.

Somerstein, L. (2010). Together in a room to alleviate anxiety: Yoga breathing and psychotherapy. Procedia, Social and Behavioral Sciences 5, 267-271. https://doi.org/10.1016/j.sbspro.2010.07.086

Tuckman, B. W. (1965). Developmental sequence in small groups. Psychological Bulletin, 63, 384-399. https://doi.org/10.1037/h0022100

Yalom, I. (2001). A csoportpszichoterápia elmélete és gyakorlata. Fordította Bíró Sándor. Budapest, Animula.

Vermes K. (2008). A test- saját és idegen határán. Pszichodráma Újság, Különszám a mozgás-és táncterápiáról, 115-123.

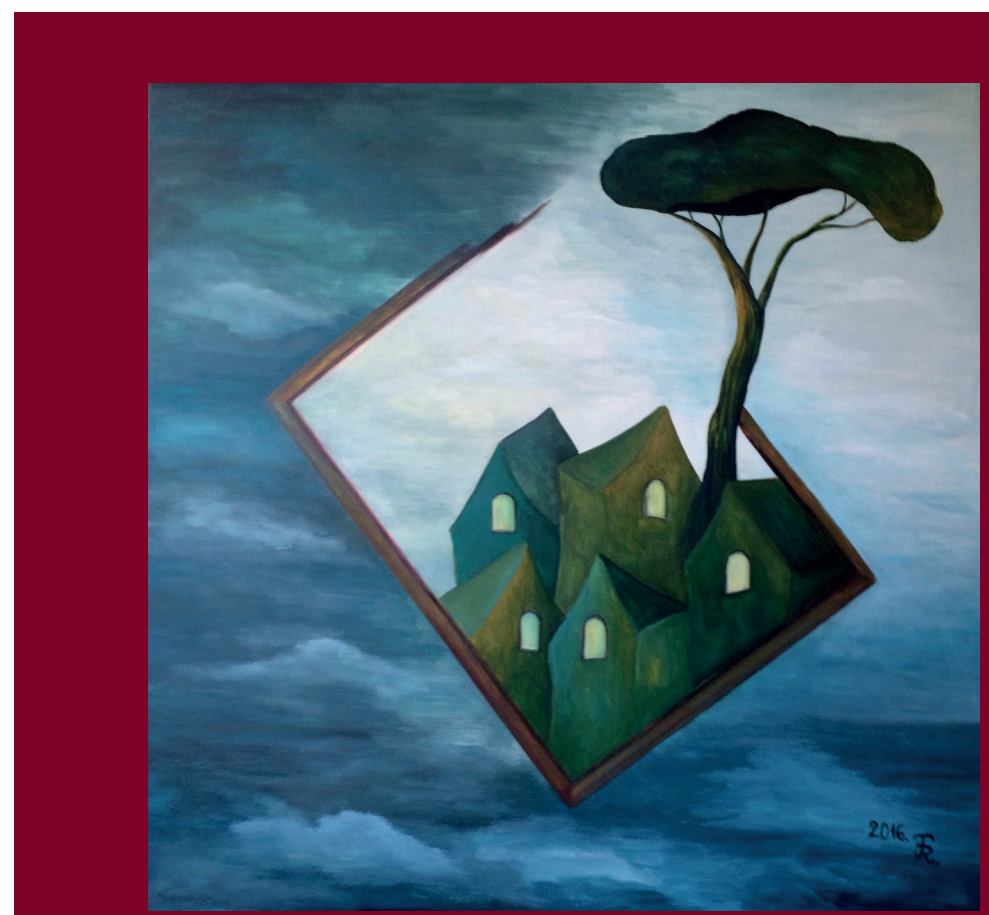




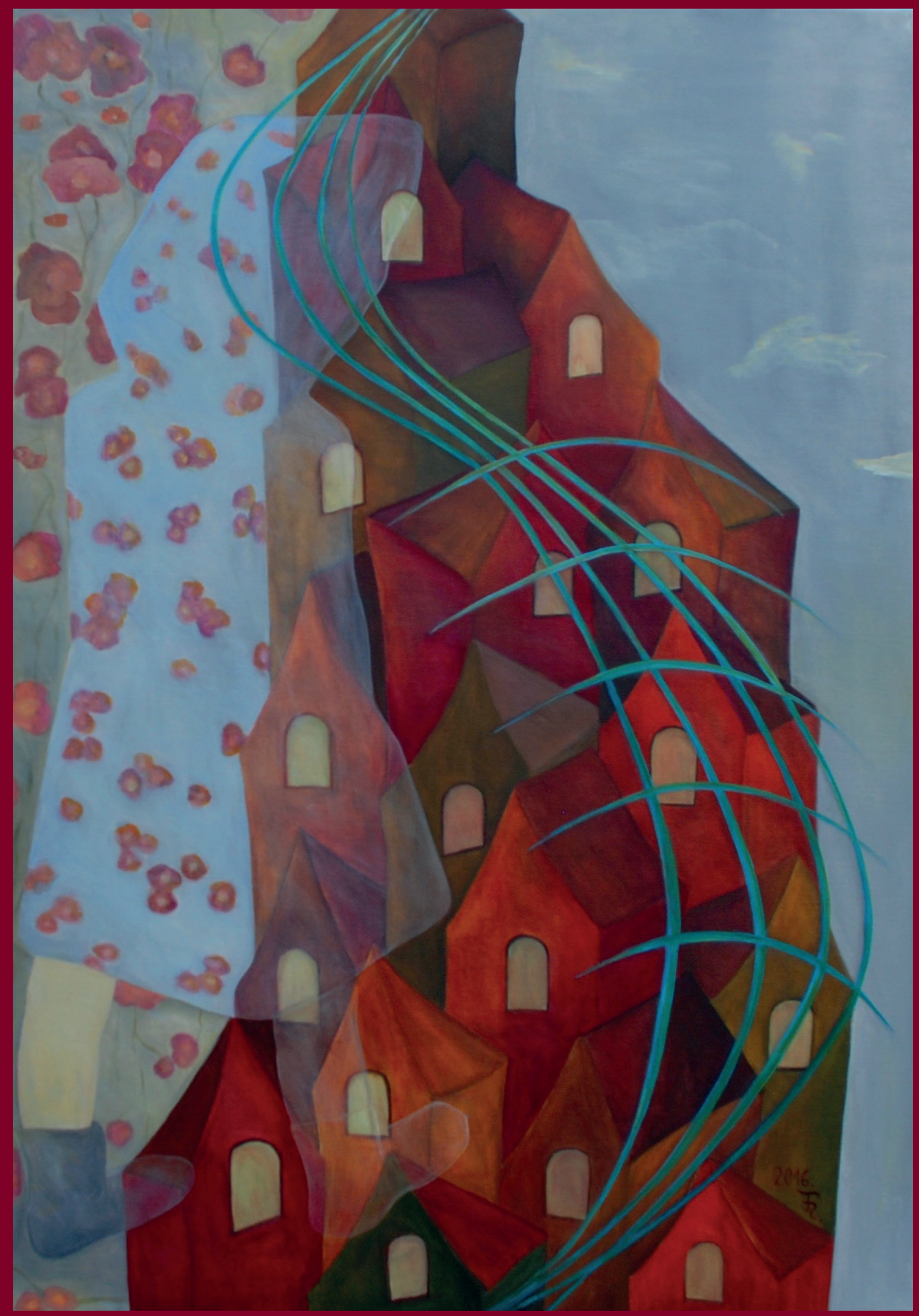

ÚTBAN A FELNÖTTSÉG FELÉ

(FEREnCZ J. RéKA) 